\title{
The Commons from a Critical Social Systems Perspective
}

\author{
Los comunes desde una perspectiva de los sistemas \\ sociales críticos
}

\author{
WOLFGANG HOFKIRCHNER
}

TECHNISCHE UNIVERSITÄT WIEN

Article received: 09 October 2013

Article accepted: 26 January 2014

\begin{abstract}
This paper is an attempt to theorise the commons from a perspective that sets out for reconciling systemism with a critical stance.According to that the concept of the commons is not only descriptive but also normative. The commons are defined as the systemic effect of synergy in social systems. However, the more suppression and exploitation are ruling, the higher is the extent of exclusion of actors from self-organised generation and usage of the synergetic effect, that is, the higher the extent of enclosure of the commons. Actually, the trend towards the enclosure of the commons is all-embracing and besets every subsystem of society. The critical stance of that theoretical position manifests itself in the endorsement of the reclaiming of the commons as a step towards the implementation of a good society.
\end{abstract}

Keywords: self-organisation, synergy, enclosure of the commons, Logic of the Third, Global Sustainable Information Society

Resumen

Este artículo es un intento de teorizar los comunes desde una perspectiva que pretende reconciliar el systemism con una postura crítica. De acuerdo con esto, el concepto de los comunes no es solo descriptivo sino también normativo. Los comunes son definidos como el efecto sistémico de la sinergia en los sistemas sociales. Sin embargo, mientras mayor represión y explotación reinen, más amplio es el alcance de la exclusión de los actores por los efectos sinérgicos en cuanto a su uso y producción auto-organizada, es decir, mayor será la extensión del cercamiento de los comunes. De hecho, la tendencia hacia el cercamiento de los comunes es global y asedia a todos los subsistemas de la sociedad. La postura crítica de esa posición teorética se manifiesta por sí misma en el respaldo de las reivindicaciones de los comunes como un paso hacia la implementación de una buena sociedad.

Palabras clave: auto-organización, sinergia, cercamiento de los comunes, Lógica del Tercero, Sociedad informacional global sustentable 


\section{INTRODUCTION}

This paper explores the possibility of approaching the subject of the commons in terms of systems thinking. So far, social systems thinking has been mainly associated with Luhmann's theories. The perspective taken here, however, focuses on a post-Luhmannian paradigm that harnesses emergentist systemism for social theory (Wan, 2011) and is very close to the Relational Sociology of Pierpaolo Donati (2011). It is a realist stance and introduces Critical Theory assets to systems thinking, which is important as the subject is highly contested and needs an approach that deals with its normative aspect in an explicit way.

The paper brings forward a theoretical argument.

The first section presents the basic assumptions of a critical social systems approach as to the tools it recommends, the scope it defines, and the aim it supports.

All three dimensions reveal a Logic of the Third - of something that relates phenomena (social systems as totality), relates agents (social relationships as structure), or relates actions (social anticipations as visions). This Logic of the Third is elaborated by reference to Charles Sanders Peirce's concepts of Firstness, Secondness and Thirdness in the second section.

Section three shows that the commons fulfil the criterion of a Third: they are synergetic effects of systemic self-organisation. They reside in each subsystem of society, in the cultural, the political, the economical, the ecological and the scientific-technological subsystems and signify what is at stake in the battles of today.

In order to disclose the commons and make them accessible to all humanity and each individual in a just way, a good society must be envisaged and implemented. The fourth section argues that such a good society is a Global Sustainable Information Society.

The latter can only be reached by overcoming antagonisms that are rooted in idiotist relationships that socialise actors as self-regarding rather than regarding a Third. However, empirical data of the last section give evidence that idiotism prevails up to the present and the conditions for a transformation into a good society is not imminent.

\section{CRITICAL SOCIAL SYSTEMS PERSPECTIVE}

When developing the so-called Salzburg Approach to Information and Communication Technologies (ICTs) and Society in the years 2004 to 2010, 
the sociology of technology I used was based upon a combination of critical thinking and systems thinking - of Critical Theory and Systems Theory. Criticism and systemism both include what I use to call the Logic of the Third. The Logic of the Third is the foundation of a critical social systems theory.

"Criticism is a method oriented toward recognising and sublating of contradictions.» This is how, in the aftermath of the 1968s, Kurt P.Tudyka (1973: $9-$ my translation) put it in his introduction to critical political science. This postulate, however, is directive not only for political science but for all social science disciplines. According to it, criticism gives particular answers to three basic questions social science is confronted with:

- First, which are the tools of social science?

- Second, what is its scope?

- And third, where does it aim at after all?

That is why Tudyka's text is useful when discussing the critical stance of critical social systems thinking I'm advancing (see Table 1).

Table 1

Criticism and Systemism in Social Sciences

\begin{tabular}{|c|c|c|}
\hline & Criticism & Systemism \\
\hline Tools & $\begin{array}{l}\text { Putting of phenomena in the } \\
\text { context of social totality } \\
\text { (=the third) }\end{array}$ & $\begin{array}{l}\text { Putting of phenomena in the } \\
\text { context of social systems } \\
\text { (=the third) }\end{array}$ \\
\hline Scope & $\begin{array}{l}\text { dialectic of agency and } \\
\text { structure (=the third) }\end{array}$ & $\begin{array}{l}\text { self-organisation of actors and } \\
\text { emergent relations (=the } \\
\text { third) }\end{array}$ \\
\hline Aims & $\begin{array}{l}\text { supporting of sublation of } \\
\text { antagonisms caused by } \\
\text { heteronomy through } \\
\text { reflexion of concrete utopias } \\
\text { (=the third) }\end{array}$ & $\begin{array}{l}\text { supporting of the social } \\
\text { system's transformation into } \\
\text { higher-order states based } \\
\text { upon real possibilities (=the } \\
\text { third) }\end{array}$ \\
\hline
\end{tabular}


First, regarding the tools, Tudyka starts with the well-known quote of Karl Marx (1894) that «all science would be superfluous if the outward appearance and the essence of things directly coincided.» The method of socialscientific investigation needs to be aware of the incongruency of appearance and essence and is an attempt to reveal the essence and to reconstruct the link between the two. Tudyka writes (1973: 12 - my translation), «Criticism gains power, when it can put the object in the context of societal totality, thus recaptures its illusive empirical isolation and can demonstrate its historical all-society character. For in the isolation of single aspects criticism gets lost practically and cognitively and the surface throttles critical thought». Thus the tools that guarantee critical thinking in social methodology put the object of inquiry in the context of history and society as a whole. Social totality, then, plays the role of a Third that is sought after to connect the single aspects. By theoretically reconstructing the totality and relinking the single aspects to that third, social science is enabled to give a meaning to empirical findings and to provide scientific understanding.

Systemism - in contradistinction to positivism - is not alien to that task. Proper tools for critical social methodology can be made available from systems thinking. Every kind of systems thinking is close to the idea of casting a third in that it is a feature of them to look upon every object as immersed in an overall systems context. Evolutionary Systems Theory (which is about complex systems organising themselves, Hofkirchner 2013a) looks upon any phenomenon as process or result of a process that propels evolution of systemic interconnectedness. That way it works on a metalevel that provides a Third to weave the red thread among the object level.

This symbiosis of criticism and systemism becomes obvious when focusing on the question of the behaviour («Verhalten» in German) of social actors and the social relations («Verhältnisse» in German) between them. This question has been attracting attention anew with Pierpaolo Donati's paradigm of a Relational Sociology (2011). Behaviour can be researched empirically. Not so social relations. The latter can be found only through theoretical endeavours. Social relations are, so to speak, what is essential for the behaviour, that is, what is common because it is necessary, and can be labeled «lawful». Social relations appear in the concrete behaviour. In systems terms, they are the enablers and constraints of the actions and interaction of the actors. They determine, to a certain extent, the behaviour of the actors. The behaviour can, in a way, be understood by refering to the underlying social relations. But no behaviour can be explained by resorting to the actors or agency only. Enablers and constraints are relational, they are structural in 
nature, not actional. They are the Third that relates actors and individual agency realises only possibilities that are spanned by social relations.

Second, regarding the scope of critical social science, Marx (1852) put it in the famous words: "Men make their own history, but they do not make it as they please; they do not make it under self-selected circumstances, but under circumstances existing already, given and transmitted from the past.» These circumstances build an objective reality that human subjects cannot avoid facing when acting. That reality is known as social relations that together form the structure of society. Social theory is still divided over the question of how to conceive of the link between agency and structure. Social critique considers it a social contradiction, that is, a dialectical relationship which is said to exist once both sides of a relationship are opposed to each other, depend on each other, and neither can be replaced with the other without simultaneously replacing the mode of the relationship. In this dialectical relationship of agency and structure, structure is a Third because it relates social actors to each other. It orders the behaviour of social actors through opportunities that enlarge and/or limit their options.

In terms of Evolutionary Systems Theory, agents and structure are modeled as being coupled in a feed forward and a feedback loop, called self-organisation, which leads to the reproduction of the system or to its transformation including possible metasystem transitions which usher in new social formations. Thus the object of inquiry comprises (1) the actors that interact to form the social system and (2) the social relations emerging from, and dominating, their interaction as well as (3) the interplay of actors and relations. The actors populate the so-called micro-level of the social system, whereas the social relations are located on the so-called macro-level. The macro-level is emergent to the micro-level and exerts a downward causation on the micro-level. The macro-level plays the role of the Third.

Last but not least, regarding the aims of critical social science, Tudyka says «Science is partisan« (1973: 25 - my translation), whether you want it or not. Thus, it is necessary to reflect on its aims. Before the Positivism debate in German sociology between the Frankfurt School type Critical Theory and positivist Critical Rationalism, the context of application in which scientific knowledge is used to solve problems and is transformed into technologies, whether material or ideational, was not deemed to be scientific enough. The ideology of value-free science excluded it from pertaining to science. According to Tudyka, the task of social science should not be to mirror reality, thereby suggesting the immutability of that which needs to be changed, but it should aim at a concrete utopia that transcends the bad empirical through the category of the real possible (Tudyka, 1973:24-25). Critical social science is, in the final 
analysis, critical because it measures the empirical against the real possible that is desired. Concrete utopia (Bloch, 1967) is the Third that allows for measuring.Antagonsims that are characteristic of social relations of domination are to be revealed in order to help sublate those antagonisms.

Since the founding of General Systems Theory through Ludwig von Bertalanffy and Anatol Rapoport and others it goes without saying that Systems Theory is normative, too. It can describe spaces of possibilities that might or might not be realised by the agents. It can describe possibilities that lead from one state of the system to a state that better fulfils functions desired by the agents and marks a higher order of the social system -in which case the higher order is a good. And it can describe unsustainable states - which then are evils - and possibilities to get rid of dysfunctions harmful to agents. By describing goods and evils and how they can be set out for or left behind, systems thinking makes explicit that it is value-laden and crosses the border from description to prescription and provides a Third as standard of comparison.

\section{THE THIRD}

For a better understanding of the notion of a Third it is worth revisiting Charles Sanders Peirce's (2000) idea of firstness, secondness and thirdness.

Firstness was defined by Peirce as a relation pertaining to the lower-level of individual agents. An individual agent in itself might be interpreted as a monad that has a relation to itself only. However, such a relation is far from a full-fledged relation. It's the primordial relation, or the most derivative, if any.

Secondness was defined as a relation between two interacting individual agents. One individual agent reaches out to another individual agent. The first agent relates itself to the second one. This relation might be reciprocated by the second one or not. In any case, such a relation is not necessarily durable but volatile as it can be revoked by any side at any time. Anyway, it is a relation an agent acts out for another agent. As such, it is qualitatively different from a monadic relation. It can be named a dyad. Nevertheless, it is observable and describable and needs not necessarily a theory for explaining it. Thus, a dyadic relation is not very far from the monadic one. It is more developed than the monadic once but not yet fully unfolded. It is an intermediary step in the evolution and hierarchy of relations. In social systems, secondness is the feature of the behaviour of actors. Like the actors themselves, their behaviour, their actions, their network belong to the same systems level - the micro-level. 
Thirdness, then, was defined by Peirce as a something that establishes and mediates the relation between two other things. According to his semiotics, for instance, it is a sign that is relational; it might be called representamen that, as a third, relates an object with an interpretant (the meaning) but the sign might also comprise the object and the interpretant. That is, there is a third that is a something that has causal power over two agents in that it is able to relate them to one another -and that's what structure is capable of. This is a fully-fledged relation. It lends stability to the interaction of agents. It exists, so to say, as a triad: two relata and a relation that is not reducible to the mere interaction of independent agents but possesses a being in its own right. Relations like that go beyond mere dyads and instigate a qualitatively new level- the macro-level. In social systems it is social relations that make up the macro-level. Social relations channel the multiple and concatenated dyadic interactions by enablement and constraint.

It is important to see that only the triad fulfils the criterion of a system in the sense of an evolutionary, self-organising system; only such a system has, at least, two levels - the micro- and the macro-level.A dyad is not a system in this sense. It contains systems, if the agents are seen as evolutionary, selforganising systems. And, in fact, an agent can be seen as a such a system having a micro- and a macro-level, if the focus is on the interior of how the monad works.

It is interesting to understand that after Peirce, there is no fourthness or fifthness as he contended against Bertrand Russell who repudiated the idea of firstness, secondness and thirdness because he did not see the difference in quality between these three relations; he did not see that there was no difference in quality regarding higher orders of relations; he did not see that every higher order relation can be broken down to amounts of first-, second- and thirdnesses but thirdness cannot be broken down to secondness and firstness, and secondness cannot be broken down to firstnesses.

Thus the most important insight is to grasp that fully-fledged relations play the role of the Third and cannot be reduced to the interactional relations of agents or to the individual agents themselves. There is emergence on the way up from the agents and their interaction to the structure of the system and there is a kind of dominance the way down; thirdness shapes secondness shapes firstness. Driven by the co- and counteraction of actors the build-up of social systems locks in at certain structural possibilities that determine possibilities for the next round of interaction in which actors can, more or less consciously, choose to restrict themselves to the enablements and constraints given by the structure or to try to extend them and bring about a switch to another structure. 


\section{COMMONS}

Every product of agents self-organising into a system, or self-organising within a system, is a relational product and has the characteristic of a Third. Commons are no exception (Hofkirchner, 2013b; 2013c).

The rationale of every system is synergy. Because agents when producing a system produce synergetic effects, that is, effects they could not produce when in isolation, systems have a strong incentive to proliferate (Corning, 2003).

In social systems synergism takes on the form of some social good.Actors contribute together to the good and are common beneficiaries of that good - the good is a common good, it is a commons. That good comes into being through the common effort of actors' combined productive energies and is located on a social system's macro-level. It is a relational good that influences actors on the micro-level, since it enables or constrains the actors' participation in producing and consuming the good. It is a Third, since any build-up of social order is the build-up of something «third «. All actors contribute to the emergence of that order that grants that their interactions become stable relations. The new structure relates the actors to each other. The new structure plays the role of the «third», the actors assume the roles of the «first» (ego) and the «second» (alter).

Since the commons is an emergent quality, it cannot be fully traced down to the quantity of the contribution of each actor. There is a leap in quality that is not fully determined by the initial conditions (which play the role of boundary conditions that are necessary, but not sufficient conditions). The same holds the other way round: there is less-than-strict determinism in topdown emergence. Accordingly, the commons does not have the same impact on every actor; a quantity of the commons used by one actor may yield a different qualitative result than the same quantity yields in the case of another actor. The actors have a share in the added value when producing it and they share the added value when using it; but the share the actors have does not account for the added value produced nor does the added value produced account for how much the actors share. This problem of the lack of reciprocal accountability between costs by, and benefits for, individual actors is an argument against measurements of transactions and exchanges between individual or aggregate actors as the basis of measures to balance their rights and duties in a justifiable way; individual input to, and individual output from, the commons is rather a matter of collective action.And for that reason, the only principle of a humane organisation of production and usage of the commons that can be supported is, in general, «from each according to their ability, to each according to their need». 
In heteronomic societies, however, the production and provision of commons becomes a contested field. Antagonistic relations occur. One class of actors - the so-called dominating class - make a living at the cost of other actors - the so-called dominated classes. In the age of global challenges antagonisms have been aggravating. The social (cultural, political, economic) crises, the ecological crises and the scientific-technological crises we are witnessing reveal more and more that they are battles over the whole spectrum of commons - battles that put the survival of humankind at risk. Each crisis appears in a specific social subsystem and is a conflict about the commons specific for that subsystem.

In society as a social system, the common good is the inclusive community of actors or, more precisely, the societal relations that condition the ideational 'who, what and how' - the social subject, the social object, and the social ways and means - of human activities that include the material and natural ones but go beyond mere physicality; the commons is the sphere that allows for the unfolding of individual ingeniousness, the space that society provides for it; it is,

- in the cultural subsystem, the realm of values or, more precisely, the societal relations that condition the process of defining what (a) good is in a good life;

- in the political subsystem, the public sphere or, more precisely, the societal relations that condition the decision process on the conduct of a good life;

- in the economic subsystem, the field of resources or, more precisely, the societal relations that condition the distribution of the means for a good life.

All social subsystems have become battlefields of the struggle for inclusion against exclusion:

- the cultural subsystem has become the battlefield of the struggle for inclusive definitions of selves having in mind unity through diversity as against parochial ways of living, nationalism and fundamentalist ideologies;

- the political subsystem has become the battlefield of the struggle for participative democracy against right-wing, technocratic or populist authoritarian rule;

- the economic subsystem has become the battlefield of the struggle for unalienated working conditions and a fair share for all against the ero- 
sion of the labour force, against the pressure exerted by the financial capital, against corruption, against the Matthew principle (the rich-getricher mechanisms) inherent in capitalist economies, etc.

In the ecological subsystem of society -in which actors produce adaptations to, or of, the natural environment that support human self-preservation- the common good is the whole human nature and the whole natural environment or, more precisely, societal relations that condition the material 'what' and the material 'who', the natural object and the natural subject, of human activities, the ecology and the bodies. This system has turned into a battlefield of external and internal nature: there is the struggle for a cautious treatment of the bio-physical bases of human life against their extensive and intensive colonisation.

In the scientific-technological subsystem of society - in which actors produce scientific-technological innovations that enhance and augment human self-actuation - the common good is science and technology or, more precisely, societal relations that condition the material -the natural ways and means - of human activities, the physical tools and procedures. This system is now a battlefield of the struggle for science as a "communist», universal, disinterested and organised skeptical endeavour as Robert K. Merton put it 1942 in «The normative structure of science» (1973:267-278), for technology assessment and for designing meaningful technology as against military-industrial-complex funded research and development.

\section{COSMOPOLITANISM}

The transformation of these conflicts over the commons and the sublation of these antagonisms would require actors that overcome their restricted abilities for action and extend them to include the concern for a good society. A good society, given the global challenges, needs to exist on a planetary scale, that is, it needs to be global; it needs to be capable, by establishing its organisational relations, of acting upon the dangers of anthropogenic breakdown, that is, it needs to be sustainable; and it needs to be capacitated, by means of ICTs, to create requisite wisdom, knowledge, data, that is, it needs to be informational. Such a society is called a Global Sustainable Information Society (GSIS) (Hofkirchner, 2013c; 2011; 2013b).

The GSIS is rather a framework of necessary conditions to be met in order to avoid the breakdown of the worldwide web of social systems today than a detailed blueprint. What are needed for its implementation, anyway, are individuals, social subjects, social systems, whose concerns are with 
civil society, with values, and with the future of society, as Archer and Donati have emphasised (2008). What is needed is another mode of reflexivity that establishes a meta-level thinking by human minds - the emergence of something new that mediates as a third between two other things on the human mind's object level, relates them in a new way and gives them a new meaning.; by doing so, the reflexive actor repositions herself to the objectsin-reality which are her objects-in-practice (Hofkirchner, 2013b). What is needed is that the GSIS is reflected as the Third to come.

So far, human history seems to have unfolded different stages of social formations that intertwine social self-organisation and social information processes. Applying the idea of monadic and dyadic relations as not fully unfolded relations, historical stages can, in theory, be reconstructed such that a GSIS can be postulated as a possible third stage of societal evolution; the second formation is thereby a negation of the first one and the third one a possible negation of the negation. The first two social formations have been oscillating between the poles of individualism and collectivism, whereas the possible third one is to balance individuality and collectivity (Hofkirchner, 2013b) (see Table 2).

Table 2

Stages of unfolding of the social relations as a Third in the course of history

\begin{tabular}{|c|c|c|c|}
\hline & tribalism & idiotism & cosmopolitanism \\
\hline actor/structure & $\begin{array}{l}\text { personifications } \\
\text { of a "We»/ } \\
\text { relational "We» }\end{array}$ & $\begin{array}{l}\text { self-regarding "I" } \\
\text { s/competitive } \\
\text { relations }\end{array}$ & $\begin{array}{l}\text { individuals taking } \\
\text { the perspective of } \\
\text { the collective/ } \\
\text { individual } \\
\text { regarding } \\
\text { collective }\end{array}$ \\
\hline $\begin{array}{l}\text { social } \\
\text { consciousness }\end{array}$ & myths & $\begin{array}{l}\text { ideology of the } \\
\text { private }\end{array}$ & reason \\
\hline means and ends & not questionable & $\begin{array}{l}\text { flexible means for } \\
\text { given ends }\end{array}$ & $\begin{array}{l}\text { both means and } \\
\text { ends subject to } \\
\text { deliberation }\end{array}$ \\
\hline
\end{tabular}

The first stage is called «tribalism» (see Donati's typology in 2010). It appeared at the dawn of humankind in face-to-face communities: 
- the overall system is mystified as an all-embracing "We»; any actor is kind of personification of that «We»,

- myths convey tradition;

- means and ends of social life are not questioned.

The second stage deserves the name «idiotism» (Curtis, 2013). Etymology shows, «idios» meant in Greek Antiquity «the personal realm, that which is private, and one's own» (12). In Curtis' view, «idios» bears also the stamp of being enclosed». He says that «the creation of the private through the enclosure of public or commonly held resources has historically been the primary means by which property has been secured for private use» (12). By the term «idiotes», then, a person was denoted that is concerned with his personal realm only, with his own, and not with, say, the res publica and the fate of other human beings. Curtis convincingly demonstrates that neoliberalism, not only in ideology but also as a distinct social order, epitomises the principle of the «idiotes». Hence «idiotism» as signifyer of our current society. However, «idiotism» as a feature of society that functions via self-interested, selfconcerned individuals goes, in fact, back to Antiquity and even earlier social formations in which domination appeared - the institutionalised instrumentalisation of humans for one's own interests, which goes hand in hand with the enclosure of the commons and the denial of free access to the latter. Global financial capitalism is just carrying idiotism to extremes. But it originated, as demonstrated by the Odyssey, when selfish «I»s, after having disguised themselves as incarnations of the «We» overtly entered the stage of heteronomic societies:

- the actors became self-regarding persons of their own rather than other-regarding and thinking is short-sighted and does not take into consideration harmful effects on other parts of the system; the structures of the social systems have been prioritising competition on the higher levels of society over co-operation, which is reserved for the lower levels;

- in ideology the private is believed to be the supreme good;

- means and ends have been decoupled insofar as means are intelligently flexibilised whereas the final end stays given.

The third stage is called «cosmopolitanism», thereby referring to the GsIs: 
- it shall consist in a dialectical integration of the individuals but does not require their subsumption as in the first stage; it shall be based upon the diversity of individuals as in the second stage but serves their true and best interests by acknowledging that they can do so exclusively when in harmony with the overarching system and thus without doing harm to other system components; actors need to build up a unity-through-diversity relationship to the social system; actors need to be capacitated to reflect their own position and the position of others from the perspective of the overall social system; through collective reflexion of the actors the system itself can be said to be reflexive about its actors when assuring the improvement of conditions for the social synergy to come and for the decrease of social frictions in the generation and utilisation of the commons;

- it must be neither ideological nor mystified but as reasonable as possible; a realistic, science-based and practical assessment of different paths of societal development is needed;

- means as well as ends shall be questionable; no means, no ends shall be given unless agreed upon in common; not only shall the means be variable, but also the ends shall not be constants any more.

\section{HOPE FOR CHANGE}

Movements that arose in the beginnings of the current crises in the economic subsystems such as the like the Indignados or the Occupy movement are part of a many events that can be looked upon as foreshadowings of a GSIS.

However, the societal development after the 1968s was not particularly conducive to the formation of strong, comprehensive, deep forces made up of agents of change in the direction of a GSIS. In the aftermath of the oilcrises in the first half of the seventies and on the eve of the eighties of the last century, the postwar boom and the blind trust in the steady improvement of social life conditions lost momentum. In economy, the accumulation of industry capital decoupled the increase of wages from the increase in productivity. In technology, flexible automation displaced Fordism (mass production with mass consumption). In politics, Thatcherism and Reagonomics, the destruction of the social welfare state by liberalisation, privatisation, and deregulation were introduced. In culture, the ideology of neoliberalism, of "make your own luck», of individualism began to become hegemonic. All of that formed a pattern that connects. It was implemented by the advised response of the ruling classes to the decline of the profit rates 
which had accelerated because of the accumulation of capital that could not find appropriate spheres of investments. And this implementation could capitalise the weakness of the trade union and labour movements. In the nineties, the financial capital began to outweigh the industrial, «material», «productive» capital causing several bubble implosions. In the current crises, the transnational financial capital is targeting national economies and the politicians support it by administering austerity at the cost of the 80,90 or even 99 per cent of the populations instead of starting a redistribution of wealth and income.

Before Against this historical background, the development of alternative consciousness was rather improbable, since pupils were trained for working as cogs in short-sighted economic interests and were not educated for grasping the big picture. Personal competence through political education and engagement is lacking, whereas technical and business skills and (natural) science education prevails. This is the result of the economisation of education and the transformation of pupils and students in customers. "There is no room any more for education of man for critical self-reflection in institutions that are reduced to the training function and that are reduced to conveying occupational information and skills in an economically efficient way» (Heinzlmaier, 2012: 5-6 - my translation, W. H.). These institutions do not provide guidance for critical thinking nor do they provide free space for it. Bonds to society are not established.

Youth studies reflect that situation. In 2002, the 14. Shell Jugendstudie coined the term "pragmatism» of the German youth which had a constructive connotation. 4 years later, the follow-up study had had to find out that the pragmatic generation had been put under pressure by the economic development (Hurrelmann, 2006:31). It had become more difficult to implement one's projects. In the 16. Shell Jugendstudie (2010) the following ideals show a slight increase compared to 2002, ordered according to frequency of response from 12 to 25 years of age (http://s04.static-shell.com/ content/dam/shell/static/deu/downloads/youth-study-2010values.pdf):

- friends (97\%)

- family (92\%)

- live and act autonomously (90\%)

- be hard-working and ambitious (83\%)

- enjoy life to the full (78\%)

- high living standard (69\%)

- help socially disadvantaged (58\%). 
Thus Heinzlmaier talks of «pragmatic individualism» (2012: 4). A more indepth analysis shows: youth is segregated. According to the 16. Shell Jugendstudie (2010), only fourty per cent of the young Germans at the bottom of society are satisfied with their situation compared to 84 per cent at the top (http://s00.static-shell.com/content/dam/shell/static/deu/downloads/ youth-study-2010satisfaction.pdf). Nearly 10 per cent of the German youth belongs to the so-called "precariat» which is decoupled from societal development (Heinzlmaier, 2012: 2). It would need more than one generation to reintegrate them. «It's bad if people are exploited but even worse if they aren't needed for exploitation any more» (Negt, 2012: 195 - my translation, W. H.).

Furthermore, says Heinzlmaier, though in so-called knowledge societies, reputation, income and social security depend on the level of education, graduates of education at the compulsory school level and trainees do not earn more than to live a «materialistic» life style only. They use the material gratifications through their job for consuming branded goods to make them distinctive from other groups whereas only graduates of a humanistic secondary education and students of humanities and arts seem to tend towards a «postmaterialistic» life style.

In a recent survey carried out on the basis of so-called Sinus-Milieus, 50 explorative interviews and 1.500 online interviews represent results for the young Austrians from the age of 14 to 29 years (INTEGRAL, T-FACTORY 2013). According to it, youth is split in several milieus according to which these groups develop different strategies for making their ways (in the following, these groups are ordered from the biggest one to the smallest one).

- The «hedonists» form the biggest group (more than 20 per cent). Mostly, they stem from a disadvantaged social stratum. They look for a niche for survival, live in the here and now and are described as emotional and spontaneous. They have a low level of education.They don't see opportunities for them in the future. In the web they look for games and entertainment.

- The «adaptive-pragmatics» reach 18 per cent. Their parents belong mostly to the middle of society. They are flexible, oriented to the feasible, and hard-working, but are not as optimistic. They use Social Networking Sites for keeping in touch with their friends.

- The «digital individualists» form a group as big as the former. Their parents are well-off. They are creative and confident to carve out their own place due to their better education. Information and Communication Technologies are part of organising their everyday life. 
- The «conservative-bourgeois» are almost as strong as the two groups above (17 per cent). They stick to the old values, set a high value on family and home and show self-discipline rather than self-development. They are optimists. They are skeptical of the new media.

- The «performers» have a share of 15 per cent. Their parents live at ease. They are imperturbable optimists and are convinced of being able to hold their ground in a globalised world. They are career-fixed and believe in good opportunities to earn money. They use Social Networking Sites for their career.

- The «postmaterialists» form the smallest group (10 per cent). They are critical as to consumption and «materialism». They are optimistic as to their own fate but extremely pessimistic as to the fate of society though they are engaged with politics. Like the conservative-bourgeois they are rather skeptical of the new media.

With regard to the reflection of society and one's position in it, a striking schizophrenia is obvious in the findings. An overall share of 59 per cent of the German youth is optimistic, according to the 16. Shell Jugendstudie (2010), and only 6 per cent are pessimistic (http://s04.static-shell.com/content/dam/ shell/static/deu/downloads/youth-study-2010optimism.pdf). The Austrian study (INTEGRAL, T-FACTORY 2013) presents similar findings: almost two thirds of the young Austrians look optimistically ahead, and positive thinking is regarded a must in personal matters. However, it is more detailed: at the same time it finds that only short of one quarter is optimistic for the future of society.That is, a majority believes to succeed in muddling through in spite of being part of society the development of which is expected to deteriorate.

Summing up, and assuming that these studies referring to Germany and Austria can be generalised for other countries with similar societal background, there is no empirical evidence for the spread of consciousness among the youth in the Western world concerned with the Third of the commons that need to be reclaimed for a just order of the social relations in the nascent world society. The crises of recent years exaggerated the conflict between the ideology of endless opportunities and the experience of a reality with restricted opportunities and a lack of generally binding ideals. The Arab Spring and concomitant movements like those of the 'Indignados' in Spain or 'Occupy' worldwide can be interpreted as upheavals of the frustrated «materialists» rather than expressions of autonomy-oriented "postmaterialists». The motives by which they were and still are moved are «concern for the job, the starting of a family, securing status, and the future at 
large» (Kraushaar, 2012: 209 - my translation). So restricted reflexion seems the dominant mode.

But there is still hope. For these protests have, at the same time, been fostering the germ of growing political awareness, reflecting the economic background and of a will to change «that not only aims at the improvement of individual positions but also focuses on the political and economic structures and discourses and aims at changing more than one's own situation for longer periods» (Heinzlmaier, 2013: 56 - my translation). Indeed, this germ has not developed. What remains, however, is the following: «In the aftermath of a revolution ideas so far exclusively associated with marginal madmen are in a breath promoted to an accepted foundation of the discourse» (Graeber, 2012: 176 - my translation). In that vein, insight into the causes of the crises may have proliferated. Discourses may have realised that the current crises are expressions of a progressive enclosure of all the common goods that are generated and utilised by actors in the whole range of social systems that make up society. Battles over reclaiming the commons may be more easily identified than before - by the people and the social scientists as well.

And there is still a foundation for hope, since social evolution as any evolution of self-organising systems inheres imponderabilities, contingencies and serendipity - it is emergent, and situations might occur that open new windows to the future.

\section{CONCLUSION}

The argument is that the commons can be described in systems terms while retaining its normative implications. Systemism and criticism can go together. That which is commonly produced for common usage is a Third that emerges from the interaction of actors. Because of relations of domination which one group of society imposes on another group - commons are privately enclosed. A Global Sustainable Information Society needs to reclaim the commons for all. However, the development of social relations after the 1968s shows that youth is not yet prepared for the requested change.

\section{REFERENCES}

16. SHeLl JugendSTUdie (2010): Jugend 2010. Eine pragmatische Jugend bebauptet sich [http://www.shell.de/aboutshell/our-commitment/shellyouth-study/2010.html]. 
Bloch, E. (1967): Das Prinzip Hoffnung, 3 vols, Frankfurt, Suhrkamp.

Corning, P. (2003): Nature's Magic, Synergy in Evolution and the Fate of Humankind, Cambridge, Cambridge University Press.

Curtis, N. (2013): Idiotism. Capitalism and the Privatisation of Life, London, Pluto Press.

Donati, P. (2008): «Discovering the Relational Character of the Common Good» in Archer, M. S. and P. Donati (eds.) (2008): Pursuing the Common Good: How Solidarity and Subsidiarity Can Work Together, Vatican City, Vatican Press.

- (2011): Relational Sociology. A New Paradigm for the Social Sciences, Milton Park, UK, Routledge.

Graeber, D. (2012): Inside Occupy, Frankfurt, Campus

HeInzlmaier, B. (2012): Keine Mission, keine Vision, keine Revolution? Die postmoderne Jugend zwischen Pragmatismus und Idealismus [http:// jugendkultur.at/wp-content/uploads/keine_mission_heinzlmaier_2012. pdf].

- (2013): Performer, Styler, Egoisten-Über eine Jugend, der die Alten die Ideale abgewöbnt haben, Berlin, Archiv der Jugendkulturen Verlag.

HofkirCHNER, W. (2011): «Information and Communication Technologies for a Good Society» in Haftor, D. M. and A. MirijamdotTer (eds.) (2011): Information and Communication Technologies, Society and Human Beings: Theory and Framework, Hershey, Pennsylvania, Information Science Reference.

- (2013a): Emergent information.A Unified Theory of Information framework, Singapore, World Scientific.

- (2013b): «Self-Organisation as the Mechanism of Development and Evolution in Social Systems» in Archer, M.S. (ed.) (2013): Social Morphogenesis, Dordrecht, Springer.

- (2013c): «Potentials and Risks for Creating a Global Sustainable Information Society» in Fuchs, C. and M. SANdoval (eds.) (2013): Critique, Social Media and the Information Society, London and New York, Routledge (in press).

HurrelmanN, K. et al. (2006): «Eine pragmatische Generation unter Druck Einführung in die Shell Jugendstudie 2006» in Hurrelmann, K. et al. (eds) (2006): Jugend 2006. 15. Shell Jugendstudie, Frankfurt am Main, Fischer Taschenbuch Verlag.

INTEGRAL, T-FACTORY (2013): Manche wollen mebr Sicherbeit, manche mebr Erlebnis und Abenteuer - aber alle Jugendmilieus arrangieren sich mit einer komplexen Welt, Medieninformation [http://www.integral.co.at/down- 
loads/Pressetext/2013/04/Pressetext_Sinus_Milieu_Jugendstudie_2013_-Apr_2013.pdf].

Kraushan, W. (2012): Der Aufrubr der Ausgebildeten. Vom Arabischen Frübling bis zur Occupy-Bewegung, Hamburg, Hamburger Edition.

Marx, K. (1843): A Contribution to the Critique of Hegel's Philosophy of Right. Introduction [http://www.marxists.org/archive/marx/works/ 1843/critique-hpr/intro.htm].

- (1852): The Eighteenth Brumaire of Louis Bonaparte [http://www.marxists.org/archive/marx/works/1852/18th-brumaire/ch01.htm].

- (1894): Capital, Vol. III. [http://www.marxists.org/archive/marx/ works/1894-c3/ch48.htm].

Merton, R. K. (1973): The Sociology of Science: Theoretical and Empirical Investigations, Chicago, University of Chicago Press.

Negt, O. (2012): Der politische Mensch. Demokratie als Lebensform, Göttingen 2012 [http://www.ams.at/_docs/001_am_bildung_0112.pdf. 10].

Peirce, C. S. (2000): Semiotische Schriften, Frankfurt am Main, Suhrkamp.

TudyKa, K. P. (1973): Kritische Politikwissenschaft, Stuttgart, Kohlhammer.

WAN, P.Y-Z. (2011): Reframing the Social.Emergentist Systemism and Social Theory. Farnham, uk, Ashgate. 